\title{
Judicial Review of the War Power
}

\author{
LOUIS FISHER \\ Congressional Research Service
}

\begin{abstract}
From the Vietnam War to the present, there has been a growing impression that federal courts lack both the jurisdiction and the competence to decide war power disputes. Such a cramped view finds no support in the first century and a half, when courts regularly accepted and decided such cases. It was only with Vietnam that courts began to avoid the merits of war power cases by invoking a variety of threshold tests. Following $9 / 11$, the broad and expansive justifications of unilateral presidential powers by the Bush administration forced federal courts to revisit and reassert their constitutional responsibilities.
\end{abstract}

The terrorist attacks of $9 / 11$, followed by the creation of a military tribunal, treatment of detainees, and passage of the USA Patriot Act, brought to the fore again the question of what role federal courts should play in policing the war power. Contemporary legal studies often argue that foreign affairs - and particularly issues of war and peace-lie beyond the scope of judicial jurisdiction and competence. However, the record over the past two centuries demonstrates that not only have courts decided war power issues many times, they have curbed presidential military actions in time of war.

Political scientists have done much to promote the belief in a strong presidency, giving short shrift to legal considerations or constitutional sources of power. The foremost exponent of this view was Richard Neustadt, whose Presidential Power appeared in 1960 , in a paperback edition in 1964, and was reissued in various formats over succeeding years. He is best known for defining presidential power as "the power to persuade" and he seemed to accept the constitutional system of checks and balances when he referred to political power as "a give-and-take" (Neustadt 1964, 23, 43). Famously, he said that the Framers created a government of "separated institutions sharing powers" (ibid., 42, emphasis in original).

Louis Fisher is senior specialist in separation of powers with the Congressional Research Service, the Library of Congress. This article draws from a lengthier report uritten with Nada Mourtada-Sabbah, Is War Power a Political Question?, CRS Report RL30687 (September 25, 2000).

AUTHOR'S NOTE: The views expressed in this article are personal, not institutional, and are not intended to reflect the opinions of the CRS or the Library. 
Elsewhere in the book, however, Neustadt showed little interest in the Constitution's allocation of power. He praised presidents for decisiveness, taking the initiative, and being the "man-in-charge" (ibid., 166). There seemed little need to persuade or to engage in give-and-take. Neustadt wrote the book for "a man who seeks to maximize his power" (ibid., 171). He measured presidential success in terms of action, vigor, decisiveness, initiative, energy, and personal power. In the Afterword, published in the 1964 paperback, he placed the war power squarely in the president: "When it comes to action risking war, technology has modified the Constitution: the President perforce becomes the only such man in the system capable of exercising judgment under the extraordinary limits now imposed by secrecy, complexity, and time" (ibid., 187-88). When war comes, the president "now becomes our system's Final Arbiter" (ibid., 189).

This was a strange formulation. First, Neustadt never examined republican principles, constitutional text, or the intent of the Founding Fathers to reach his conclusion about the legitimacy of presidential war power. He simply just announced it, independent of any legal analysis. It is strange for a second reason. Neustadt focused on the problems that President Harry Truman encountered when he seized steel mills in 1952 to prosecute the war in Korea. Federal courts heard the arguments put forth by the Justice Department, claiming broad and unreviewable emergency powers for the president, and decisively rejected them. Neustadt stands among other political scientists and historians who have justified unilateral presidential wars (Fisher 2005a).

The record from 1789 to the Steel Seizure Case of 1952 is replete with court cases that scrutinized presidential claims for emergency power and frequently found them wanting. It was only with the Vietnam War that courts began to systematically avoid war power questions. For several decades courts acquiesced to the elected branches, routinely relying on various threshold tests to deny plaintiffs the opportunity for relief. After $9 / 11$, courts initially deferred to presidential actions, but slowly judges began to challenge executive branch claims and finally, on June 28, 2004, the Supreme Court entered the fray by issuing decisions that announced its intention to supervise and limit presidential power. Those rulings were notably vague and cautious, but a number of subsequent decisions in the lower courts have been far more assertive and bold in rejecting executive arguments.

\section{Political Questions in Time of War}

Political questions are issues of law or public policy that the courts decide not to settle, leaving them to the elected branches to resolve. In Marbury v. Madison, Chief Justice John Marshall recognized that some discretionary actions by other branches lie outside the scope of judicial review. The Constitution invested the president "with certain important political powers, in the exercise of which he is to use his own discretion, and is accountable only to his country in his political character, and to his own conscience." Political questions submitted to the president "can never be made in this court."

1. Marbury v. Madison, 5 U.S. (1 Cr.) 137, 164 (1803).

2. Ibid., 170 . 
Nothing in this general formulation implied that presidential initiatives over the war power fell outside the scope of judicial review. On the contrary, it was well understood at that time that the decision to take the country from a state of peace to a state of war rested with the legislative branch, not with the president. Courts were ready and willing to protect Congress from executive encroachments.

The notion that courts are poorly suited to decide war power and foreign affairs issues does not emerge until after World War I. The legal literature began to treat matters of foreign policy, war, and peace as beyond the scope of judicial cognizance. That position, appearing in a series of law review articles in the 1920s, attracted a wide following (Gold 1923, 50-51; Finkelstein 1924, 347; Weston 1925, 315-16). That attitude spread to contemporary scholarship. Foreign affairs were thought to constitute "the core of political questions cases," and war powers--as "the most sensitive and critical manifestation of the exercise of foreign relations"-represented "the nub of the core" (Firmage 1977, 81). Analysts regarded foreign affairs and warmaking issues as categories par excellence for the application of the political question doctrine (Henkin 1996, 143). A standard reference work on the war power refers to foreign relations as a political question (Wormuth and Firmage 1986, 232), while an article in a 1985 law review adopts the same position (Champlin and Schwarz 1985, 216-17).

Part of this development in the law reflects the decision of the Supreme Court in Baker v. Carr (1962) to offer broad guidelines for the types of issues better left to the political branches. The Constitution may textually commit an issue to another branch, or there is a lack of "judicially discoverable and manageable standards for resolving" the dispute. Other reasons to avoid a decision: the impossibility of deciding a matter "without an initial policy determination of a kind clearly for nonjudicial discretion," the impossibility of a court resolving an issue without expressing a lack of respect for another branch, "an unusual need for unquestioning adherence to a political decision already made," or "the potentiality of embarrassment from multifarious pronouncements by various departments on one question." Those rubrics were later adopted by judges in the Vietnam cases.

Writing in 1992, Thomas M. Franck noted that some judges refrained from examining the legality or the constitutionality of actions once it has been asserted that the president and his subordinates "acted in the name of foreign policy or national security. According to this line of reasoning, courts may not inquire whether soldiers are being sent lawfully into combat or whether members of Congress have been deprived of their constitutional role in the decision to go to war" (Franck 1992, 4). Describing judicial precedents before World War I, Christopher N. May asserted that the Supreme Court, "with one short-lived exception-refused to pass on the validity of laws adopted under the war powers of the Constitution" (May 1989, vii). His study ignores the great wealth of war power cases previously decided by the courts. In 1999, Martin S. Sheffer offered this analysis: "One must constantly remember that executive-legislative conflicts regarding questions of emergency, war, and peace, although raising many constitutional controversies, rarely find their way to the judiciary and, when they do, are rarely decided 
according to proper constitutional interpretation. For the most part, they are resolved ... through political settlements agreed to by Congress and the President" (Sheffer 1999, ix). The courts, he says, try to avoid ruling on questions of the conduct of commanderin-chief and war powers "and when they are forced to rule, they usually uphold presidential action" (ibid., $x$ ). In fact, courts took those cases and often came down against executive actions.

A close examination of judicial rulings over the last two centuries reveals that the automatic association of war power with the political question category is a misconception. Not only did courts decide war power issues, they sometimes spoke against the authority of the president to venture in warmaking activities against the express will or the silence of Congress. The fact that some of the earliest of these decisions were written by justices who had been members of the Constitutional Convention or participated in state ratifying conventions lends additional weight to the importance of these early interpretations.

\section{From 1789 to 1861}

Beginning in 1800 , the Supreme Court accepted a war power case and disposed of it as with any other legal or constitutional issue. At no time from that decision to the Civil War did the Court express a reluctance to handle these cases, either because of a lack of competence or a fear that in deciding such disputes it might collide with the other branches. The cases involved such sensitive questions as deciding whether France was an "enemy," conflicts between presidential war proclamations and statutory policy, suspension of the writ of habeas corpus, calling forth the militia, annexing territory as the result of military conquest, and protecting American lives and property abroad. Those cases came to the courts and were decided there.

As a result of French interference with American shipping in the 1790s, Congress suspended commercial intercourse with France and enacted legislation to prepare for military. operations. The Supreme Court decided three cases resulting from the "Quasi-War" with France, which lasted from 1798 to 1800 . The first case was decided in 1800 , involving a claim by a captain for compensation regarding the recapture from the French of a U.S. merchant ship. Was the captain entitled to compensation under a 1798 act of Congress, or a higher amount based on a 1799 act of Congress governing the recapture of ships from the "enemy"? In Justice Salmon P. Chase's terms, the whole controversy turned on whether France was at that time an enemy. If it was, the law entitled the captain to one half of the value of the ship and cargo for salvage. If France was not an enemy, he would receive no more than one eighth. ${ }^{4}$ The Court was asked to decide whether, in the absence of a formal declaration of war, the state of hostilities between the United States and France amounted to a war, justifying the higher compensation. The Court ruled that the conflict amounted to war whether Congress issued a formal declaration or enacted legislation authorizing military action. War could be either declared ("perfect") or unde- 
clared ("imperfect"). In this first decision on a war power issue, not only did the Court not decline adjudication but it fully addressed the question of whether France was an enemy of the United States within the meaning of congressional statutes.

The following year, Chief Justice Marshall had his first opportunity to address a war-related issue. Silas Talbot, captain of a U.S. ship of war, captured a merchant ship flying a French flag. The owner of the ship sued the captain in libel for the value of the ship. Treating the seizure as legal, the Court ruled in favor of Talbot. To decide his rights, it was necessary to examine the relative situation between the United States and France at the time of the recapture. The Court had no difficulty in determining which branch possessed the war power: "The whole powers of war being, by the constitution of the United States, vested in congress, the acts of that body can alone be resorted to as our guides in this inquiry." To determine the constitutional question, the Court focused on what Congress had provided by statute.

The Court grounded its decision not on presidential policy but on the sole authority of Congress to undertake such seizure. As noted in one study, "Once Congress occupied the field, it had the exclusive authority to determine the scope of hostilities" (Corn 1998, 208). Edward S. Corwin pointed out that "the language of the Justices in these early cases implies that any act of war, to be entitled to judicial recognition as such, must be ascribed to congressional authorization" (Corwin 1957, 438, note 95).

A third case from the Quasi-War involved a proclamation by President John Adams to seize ships sailing to and from French ports. Congress had only provided authority to seize ships sailing to a French port. Could a president, in time of war, exceed statutory authority, and could such disputes be litigated in court? The Supreme Court took the case and decided against the president. Chief Justice Marshall said that when national policy is defined by statute, presidential "instructions cannot change the nature of the transaction, or legalize an act which without those instructions would have been a plain trespass." 6

In the Neutrality Act of 1794 , Congress prohibited American citizens from providing any assistance to military expeditions against "a foreign prince or state, with whom the United States are at peace" (1 Stat. 387, § 7). Col. William S. Smith, indicted for engaging in military action against Spain, claimed that his action "was begun, prepared, and set in foot with the knowledge and the approbation of the executive department of our government." Far from shying away from the dispute, a circuit court reviewed Smith's assertion and forcefully rejected his argument: "The president of the Unired States cannot control the statute, nor dispense with its execution, and still less can he authorize a person to do what the law forbids."

Smith asked the court to subpoena the secretary of state to determine whether Smith had acted pursuant to presidential instructions. The court decided that the testimony of the secretary of state would be of no value. Congress had already established

5. Talbot u. Seeman, 5 U.S. (1 Cr.) 1, 28 (1801).

6. Little v. Barreme, 2 Cr. (6 U.S.) 170, 179 (1804).

7. United States v. Smith, 27 Fed. Cas. 1192, 1229 (C.C. N.Y. 1806) (No. 16,342).

8. Ibid., 1230. 
national policy and the president had no independent constitutional authority to direct military expeditions on the part of private citizens. The court distinguished between the president's "defensive" power to resist invasion and the "offensive" authority of Congress to undertake military actions against foreign countries. There was "a manifest distinction between our going to war with a nation at peace, and a war being made against us by an actual invasion, or a formal declaration. In the former case, it is the exclusive province of congress to change a state of peace into a state of war." Does the president, the court asked, "possess the power of making war? That power is exclusively vested in congress." 10

In 1807, Chief Justice Marshall wrote for the Court in a case involving a motion for habeas corpus to bring up Samuel Swartwout and Erick Bollman, both charged with treason for levying war against the United States. Marshall, after first noting that the power of a U.S. court to award the writ "must be given by written law," 11 found that authority in Section 14 of the Judiciary Act of 1789 . He underscored the plenary prerogative of Congress over the decision to suspend the writ: "If at any time the public safety should require the suspension of the powers vested by this act in the courts of the United States, it is for the legislature to say so. That question depends on political considerations, on which the legislature is to decide. Until the legislative will be expressed, this court can only see its duty, and must obey the laws." 12 Following his decision, the two prisoners were brought before the Court. The Court decided that there was not sufficient evidence to justify the commitment either of Swartwout or Bollman on the charge of treason in levying war against the United States.

In 1814, the Court faced the question of whether enemy property found on land at the commencement of the War of 1812 could be seized as a necessary consequence of the declaration of war against England. The Court found that the declaration by Congress did not contain authorization for the seizure. Because Congress had not conferred any explicit authorization, there was no legal basis for seizing enemy property found on U.S. territory at the beginning of the hostilities. Chief Justice Marshall ruled that Congress had not authorized the confiscation of enemy property located within the United States at the declaration of war. ${ }^{13}$ The question of what should be done with enemy property found on U.S. territory when war begins was a question of policy "for the consideration of the legislature, not of the executive or judiciary." 14

Article I, Section 8 of the Constitution empowers Congress to "provide for calling forth the Militia to execute the Laws of the Union, suppress Insurrections and repel Invasions." In 1827, the Supreme Court addressed the issue of whether the president had authority under U.S. law to call forth state militia to repel invasion from abroad and to suppress internal insurrections. The Court decided that when Congress delegates to the

9. Ibid., 1230.

10. Ibid.

11. Ex parte Bollman, 4 Cr. (8 U.S.) 75, 94 (1807).

12. Ibid., 101.

13. United States v. Brown, 12 U.S. (8 Cr.) 110, 128 (1814).

14. Ibid., 128-29. 
president its constitutional power to call forth the militia, the judgment and discretion as to the use of force rest with the commander in chief. Speaking for the Court, Justice Joseph Story said: "We are all of opinion, that the authority to decide whether the exigency has arisen belongs exclusively to the president and that his decision is conclusive on all other persons." ${ }^{15}$ Although the case acknowledged a broad discretionary power for the president, it required the Court to examine and interpret the statutory policy enacted by Congress: "Whenever a statute gives a discretionary power to any person, to be exercised by him, upon his own opinion of certain facts, it is a sound rule of construction, that the statute constitutes him the sole and exclusive judge of the existence of those facts. And in the present case, we are all of opinion that such is the true construction of the act of $1795 . " 16$

In 1849, in a case often considered "the classic representation of the early political question doctrine" (Redish 1984-85, 1036), the president's power to call out the militia and declare martial law was again before the Supreme Court. The case arose from the Dorr rebellion of 1842 against the charter government of Rhode Island. When asked to determine whether the charter government violated the guarantee of a republican form of government (Art. IV, $\S 4$ ), the court resorted to the political question doctrine to avoid considering the matter. The Court looked first at legislation enacted by Congress on February 28, 1795, providing that "in case of an insurrection in any State against the government thereof, it shall be lawful for the President of the United States, on application of the legislature of such State or of the executive (when the legislature cannot be convened), to call forth such number of the miliria of any other State or States, as may be applied for, as he may judge sufficient to suppress such insurrections." ${ }^{17}$ By that legislation, the power to decide whether an exigency had arisen was given to the president.

Delivering the opinion of the Court, Chief Justice Roger B. Taney discussed the role of the judiciary in such matters. After a president had called out the militia, based on statutory authority, could a federal court second-guess his decision? Suppose the court concluded the president had acted incorrectly. Would it then discharge those who had been arrested? If the judicial power extended that far, the guarantee contained in the Constitution might be a guarantee of anarchy, not of order. Taney conceded that the president could abuse the power placed in his hands, but if the president acted improperly or invaded the rights of the people, "it would be in the power of Congress to apply the proper remedy." 18 The Court acted with caution, but it took the case and decided it.

In 1850 , the Court offered a restrictive interpretation of the commander-in-chief clause. President James Polk had gone to Congress to ask for a declaration of war against Mexico, and Congress responded with the necessary statutory authority. Chief Justice Taney wrote that the president, as commander in chief, "is authorized to direct the movements of the naval and military forces placed by law at his command, and to employ them in the manner he may deem most effectual to harass and conquer and subdue the

15. Martin v. Mott, 25 U.S. (12 Wheat.). 19, 28 (1827).

16. Ibid., 30 .

17. Lutber v. Borden, 48 U.S. (7 How.) 1, 43 (1849).

18. Ibid., 45 . 
enemy." 19 Although the president could invade Mexico and subject it to U.S. control, "his conquests do not enlarge the boundaries of the Union, nor extend the operation of our institutions and laws beyond the limits before assigned to them by the legislative power. "20 Taney cautioned that there was a "wide difference" between the president's power and the authority conferred on the English crown: "Our own Constitution and form of government must be our only guide." 21 The president's power as commander in chief must conform to the policy that Congress establishes by law. No military conquest by the president may annex territory to the United States.

The issue turned in part on the construction of a statute enacted on July 30,1846 (9 Stat. 42). The duties imposed upon the schooner Catherine were those established by this law upon goods imported from a foreign country. The Court was asked to decide whether Tampico was a part of the United States during its control by U.S. military and naval forces. Speaking for a unanimous Court, Taney pointed out that the port of Tampico, from which goods were shipped, remained under the control of U.S. forces during the occupation. However, the president had no independent authority to enlarge the boundaries of the United States: "[T]his can be done only by the treaty-making power or the legislative authority, and is not a part of the power conferred upon the President by the declaration of war. His duty and his power are purely military." ${ }^{22}$ Far from dodging or ducking the issue, Taney decided that Tampico was a foreign port when the shipment was made.

Another Mexican War case involved a dispute over the seizure of property. Delivering the opinion of the Court, Chief Justice Taney granted a U.S. civilian trader damages for the seizure of his property by a U.S. military officer. The Court ruled that orders of a superior officer do not justify unlawful seizure. The officer had justified the seizure on several grounds, all revolving around the traditional argument of necessity. He argued that the civilian traded with the enemy, it was necessary to prevent the property from falling into enemy hands, the property was taken for public use, and he "acted in obedience to the order of his commanding officer, and therefore is not liable."23

Taney dismissed this general plea of necessity. First, he agreed with the circuit court that the civilian was not trading with the enemy. He also approved the circuit court's instructions to the jury that the officer might lawfully take possession of the goods of the trader to prevent them from falling into the hands of the enemy, "but in order to justify the seizure the danger must be immediate and impending, and not remote or contingent. And that he might also take them for public use and impress them into the public service, in case of an immediate and pressing danger or urgent necessity existing at the time, but not otherwise. ${ }^{24}$ Far from accepting the argument that decisions by military officers in the course of combat cannot be reviewed by courts, Taney insisted

19. Fleming v. Page, 50 U.S. (9 How.) 603, 615 (1850) (emphasis added).

20. Ibid.

21. Ibid., 618.

22. Ibid., 614-15.

23. Mitchell v. Harmony, 54 U.S. (13 How.) 115, 132 (1851).

24. Ibid., 133. 
that it was the duty of the court "to detetmine under what circumstances private property may be taken from the owner by a military officer in a time of war. And the question here is, whether the law permits it to be taken to insure the success of any enterprise against a public enemy which the commanding officer may deem it advisable to undertake. And we think it very clear that the law does not permit it." 25

In 1852, in a case arising from the seizure of an American vessel during the war with Mexico upon suspicion of trading with the enemy, and its condemnation as a lawful prize by an officer authorized by the president to exercise admiralty jurisdiction in cases of capture, the Court held that "[e]very court of the United States . . must derive its jurisdiction and judicial authority from the Constitution or the laws of the United States." It decided that neither the president nor a military officer may establish a court in a conquered country "and authorize it to decide upon the rights of the United States, or of individuals in prize cases, nor to administer the laws of nations." 26

A case decided by a circuit court in 1860 recognized a broad discretionary power for the president to intervene abroad to protect American lives or property. After an affront to an American diplomat in Greytown (San Juan del Norte), Nicaragua, the secretary of the Navy ordered Capt. George N. Hollins to bombard the town. An American citizen, Calvin Durand, sued Hollins for damages to his property. Hollins justified his actions as pursuant to orders from the president and the secretary of the Navy, a position sustained by the circuit court. ${ }^{27}$ The court ruled that it is to the president that "citizens abroad must look for protection of person and of property, and for the faithful execution of the laws existing and intended for their protection." 28

Congress had not legislated national policy in this area. The president thus acted without congressional guidance. As noted in one study, whether Congress "could have proscribed the use of force in Durand was not an issue that confronted the court" (Glennon 1990, 75). In 1868, however, Congress did speak on the issue, stating that "whenever it shall be made known to the President that any citizen of the United States has been unjustly deprived of his liberty by or under authority of any foreign government, it shall be the duty of the President . . to use such means, not amounting to acts of war, as he may think necessary and proper to obtain or effectuate such release, and all the facts and proceedings relative thereto shall as soon as practicable be communicated by the President to Congress" (15 Stat. 224, emphasis added). That statute remains part of permanent law (22 U.S.C. $\S 1732$ ).

\section{The Civil War}

Emergency actions by President Lincoln during the Civil War, followed by the use of military troops throughout the Reconstruction period, thrust the federal courts deep

25. Ibid., 135.

26. Jecker v. Montgomery, 54 U.S. (13 How.) 498, 515 (1852).

27. Durand थ. Hollins, 8 Fed. Cas. 111 (S.D. N.Y. 1860) (No. 4,186).

28. Ibid., 112. 
into questions of war and presidential power. The courts were generally unsuccessful in imposing their authority in these cases, but it would be too much to dismiss their record as one of judicial abdication or acquiescence. Judges continued to decide war power cases and interpret the scope of constitutional provisions, sometimes against the executive branch.

Article I, Section 9 of the Constitution provides that "the privilege of the writ of habeas corpus shall not be suspended unless when in cases of rebellion or invasion the public safety may require it." Which branch decides when public safety requires suspension of the writ? That question came before Chief Justice Taney, sitting on circuit, when President Lincoln suspended the privilege at the outset of the Civil War. John Merryman had been arrested and imprisoned on the charge of treason. Taney ordered that a petition for a writ of habeas corpus be issued. He later learned that the court's marshal had not been allowed to pass the gate of the fort where Merryman was detained, even though Taney ruled that the authority of suspending the writ belonged to Congress, not the president. ${ }^{29}$

Taney recognized that the power to see that the laws are faithfully executed belongs to the president, but he said that the president "certainly does not faithfully execute the laws, if he takes upon himself legislative power, by suspending the writ of habeas corpus, and the judicial power also, by arresting and imprisoning a person without due process of law." ${ }^{30}$ Unable to enforce his order, Taney concluded that he had exercised "all the power which the constitution and laws confer upon me, but that power has been resisted by a force too strong for me to overcome. ${ }^{31}$ He directed that his order be transmitted to the president, who would "determine what measures he will take to cause the civil process of the United States to be respected and enforced." 32

Attorney General Edward Bates advised Lincoln in 1861 that he might suspend the writ of habeas corpus during times of rebellion, "[f]or he is especially charged by the Constitution with the 'public safety,' and he is the sole judge of the emergency which requires his prompt action" (10 Op. Att'y Gen. 74, 90). The power to suspend, he explained, was placed in the hands of the president "by the Constitution and the statute law" (ibid., 91). The administration thus recognized that Congress could enter the field and limit presidential power, as it did with the habeas statute of March 3, 1863 (12 Stat. 755).

Some federal courts ruled that suspensions by the president were unconstitutional. In 1862, a district court held that the president lacked constitutional power to suspend the writ unless he received authority from Congress. ${ }^{33}$ Relying on language from Blackstone, the court warned that "once it were left in the power of any, of the highest magistrate, to imprison whomever he or his officers thought proper ... there would soon be an end of all rights and immunities." 34 According to Blackstone, Parliament alone could

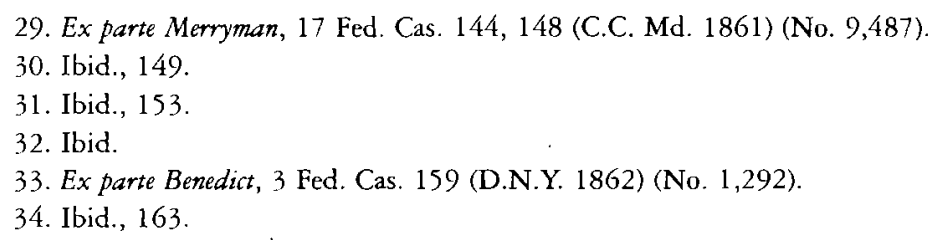


authorize the crown to suspend the habeas corpus act. ${ }^{35}$ The district court held that Chief Justice Taney's decision in Ex parte Merryman was sufficient "to show that the power of suspension is a legislative and not an executive power. ${ }^{36}$ Building on the "unanswerable argument" in Ex parte Bollman (1807), the judge concluded that the president, without authority from Congress, had no constiturional power to suspend the writ. ${ }^{37}$

In 1862, a circuit court held that the War Department had no authority to suspend the writ of habeas corpus. At the same time, the court held that President Lincoln acted properly in issuing his proclamation of September 24, 1862, proclaiming martial law and suspending the writ. ${ }^{38}$ The court referred to Martin v. Mott and Luther v. Borden in sustaining the president's power to proclaim martial law and suspend the writ in the case of military arrest. ${ }^{39}$ While critics of the administration argued that conditions did not justify martial law, "this is a question for the president, not for the court, to determine." ${ }^{40}$ Here was deference to the president, but a decision nonetheless.

In 1863, two district courts upheld Lincoln's suspension of the writ. In the first, a court ruled that his proclamation of September 15, 1863, suspending the writ, was "valid and efficient in law." ${ }^{41}$ Congress, in its statute of March 3, 1863, had authorized the president to suspend the writ. Similarly, a district court in Massachusetts considered that in view of Lincoln's proclamation to suspend the writ, it ought not to proceed further because the suspension had prevented granting the privilege asked for in the case. The district judge quoted from the 1863 statute: "That during the present Rebellion, the president of the United States, whenever in his judgment the public safety may require it, is authorized to suspend the privilege of the writ of habeas corpus in any case throughout the United States, or any part thereof." ${ }^{\prime 2}$ To the court, this grant of statutory authority was total: "No case is excepted. Not one is witheld from the operation of this power. All come within its scope, and the cases now before me are clearly comprehended in this language." 43

Lincoln's proclamation in April 1861, ordering a blockade of Southern ports in response to the rebellion, led to The Prize Cases. ${ }^{44}$ The issue was whether he had exceeded his constitutional authority by seizing neutral vessels trading with the Confederacy without a prior declaration of war by Congress. The Supreme Court addressed the nature of the rebellion and concluded that it constituted a war. The Court said it could not be asked "to affect a technical ignorance of the existence of a war, which all the world acknowledges to be the greatest civil war known in the history of the human race, and thus cripple the arm of the Government and paralyze its power by subtle definitions and

35. Ibid

36. Ibid., 165.

37. Ibid., 171.

38. Ex parte Field, 9 Fed. Cas. 1 (C.C. Vt. 1862) (No. 4,761).

39. Ibid., 8 .

40. 1 bid.

41. In re Dunn, 8 Fed. Cas. 93 (S.D. N.Y. 1863) (No. 4,171).

42. In re Fagan, 8 Fed. Cas. 947, 949 (D. Mass. 1863) (No. 4,604).

43. Ibid.

44. The Prize Cases, 67 U.S. (2 Black) 635 (1863). 
ingenious sophisms." 45 The Court decided that Lincoln's authority to use force in retaliation to a military challenge came from the Constitution and was not dependent on an authorization from Congress. "If a war be made by invasion of a foreign nation, the President is not only authorized but bound to resist force by force. He does not initiate the war, but is bound to accept the challenge without waiting for any special legislative authority." ${ }^{66}$ Yet the Court distinguished between the president's authority to order defensive actions in the midst of a civil war and the exclusive authority of Congress to initiate war against another country. The president has "no power to initiate or declare a war either against a foreign nation or a domestic State." ${ }^{47}$ The attorney representing President Lincoln took exactly the same position in court. Lincoln's actions, he said, had nothing to do with "the right to initiate a war, as a voluntary act of sovereignty. That is vested only in Congress." 48

Other legal disputes during the Civil War concerned the operation of military courts. The issue had been raised shortly before the war, in a case from 1858 . A seaman, Frank Dynes, had been charged with desertion, but the court martial found him guilty of attempting to desert. He filed an action for false imprisonment against the marshal who committed him to the penitentiary. The Supreme Court took the case, reached the merits, and undertook all the necessary legal determinations to décide that the marshal had acted properly. The marshal said that he imprisoned Dynes "by virtue of the authority of the President of the United States, in the execution of a sentence of a naval court martial, convened under an act of Congress of the 23d of April, 1800; which sentence was approved by the Secretary of the Navy, which was final and absolute. ..."49 The basis of authority was therefore statutory.

The Court pointed out that the Constitution gives to Congress the power to provide and maintain a navy, to make rules for its government, and that courts martial derive their jurisdiction and are regulated by an act of Congress. ${ }^{50}$ If persons are subject to "illegal or irresponsible courts martial," civil courts "have never failed, upon a proper suit, to give a party redress. ..." 51

In Ex parte Vallandigham (1864), the Supreme Court relied on a technical flaw of procedure to decline a review of a military trial. Clement L. Vallandigham had charged that he could not be tried by a military court. Delivering the opinion of the Court, Justice James M. Wayne held that "[t]he appellate powers of the Supreme Court, as granted by the Constitution, are limited and regulated by the acts of Congress, and must be exercised subject to the exceptions and regulations made by Congress. In other words, the petition before us we think not to be within the letter or spirit of the grants of appel-

45. Ibid., 669-71

46. Ibid., 668 .

47. Ibid.

48. Ibid., 660 (emphasis in original). The attorney was Richard Henry Dana, Jr.

49. Dynes 1 . Hoover, 61 U.S. (20 How.) 65, 77 (1858).

50. Ibid., 79,81

51 . Ibid., 81 . 
late jurisdiction to the Supreme Court." ${ }^{52}$ The dispute was avoided not by resorting to the political question doctrine but on jurisdictional grounds.

After the Civil War was over, the Court became more assertive in enforcing constitutional rights. In Ex parte Milligan (1866), the Court held that the laws and usages of war can never be applied to citizens in states where the civilian courts are open and their process unobstructed. ${ }^{53}$ Presidents could not use military courts to bypass available civilian courts. In 1876, the Court struck down a military order that attempted to annul a decree issued by a civil court concerning an issue that arose during the Civil War. The Court regarded the order as "an arbitrary stretch of authority" and considered it "an unbending rule of law, that the exercise of military power, where the rights of the citizen are concerned, shall never be pushed beyond what the exigency requires." ${ }^{\text {}} 4$

In 1866 , a circuit court reviewed a trial by military commission in Sourh Carolina. Because hostilities had ceased and the Confederate army had surrendered to federal authorities seven months before the trial, the court held on habeas corpus that the prisoner was entitled to be charged on the ground that the conviction was illegal for want of jurisdiction in the tribunal. ${ }^{55}$ The civil courts in the state were "in the full exercise of their judicial functions at the time of this trial." 56 Two years later, a district court held that Dr. Samuel A. Mudd could be tried by military commission as being an accessory to the murder of President Lincoln. ${ }^{57}$ A decision in 1867 illustrates how the Court could invoke the political question doctrine when it wanted to. The State of Mississippi sought to enjoin President Andrew Johnson from using the military to implement two Reconstruction acts. Chief Justice Chase, writing for the Court, rejected the claim that the duties placed upon President Johnson were purely ministerial and could be directed by federal judges. The Court held that it lacked jurisdiction to enjoin President Johnson from carrying out the Reconstruction statutes. ${ }^{58}$

Chase worried what would happen if the president refused to comply with the Court's order. Did the Court have the power (legal or political) to enforce its process? On the other hand, suppose Johnson complied with the Court order and became subject to impeachment by acting in contempt of congressional statutes? Would the Court then step in to support the president in opposition to the legislature? The Court had been warned by Attorney General Stanbery that the president would not obey a court order, "not out of any disrespect to this court, but out of respect to the high office which he fills." ${ }^{\text {"W }}$ Weighing these political risks, Chief Justice Chase concluded that the Court had no jurisdiction.

52. 1 Wall. (68 U.S.) 243,251 (1864).

53. Ex parte Milligan, 71 U.S. (4 Wall.) 2 (1866).

54. Raymond $v$. Thomas, 91 U.S. 712, $716(1876)$.

55. In re Egan, 8 Fed. Cas. 367 (C.C. N.Y. 1866) (No. 4,303).

56. Ibid., 368.

57. Ex parte Mudd, 17 Fed. Cas. 954 (D. Fla. 1868) (No. 9,899). Mudd's grandson later took the issue to court to clear his grandfather's name; Mudd v. Caldera, 26 F.Supp.2d 113 (D.D.C. 1998). See also Mudd v. Caldera, 134 F.Supp.2d 138 (D.D.C. 2001).

58. Mississippi v. Johnson, 71 U.S. (4 Wall.) 475, 499 (1867).

59. Ibid., 485. 
The decision regarding the commencement of hostilities belongs to the political departments, but courts have often adjudicated the termination of war. In 1870, in order to determine whether Southerners were entitled, by virtue of the act of Congress of March 2,1867 , to reimbursement for the value of their land that had been sold by the opposing forces at the time of the Civil War, the Supreme Court had to decide when the war ceased. The Court observed that in foreign wars a treaty of peace indicates termination, but in a domestic war some public proclamation or legislation was needed to inform citizens of their private rights property. ${ }^{60}$ The Court reviewed various statutes and presidential proclamations, particularly a proclamation of August 20,1866, and a statute of March 2, 1867. It also noted that Congress, in legislation for the army, "has determined that the rebellion closed the 20th day of August, 1866, [and] there is no reason why its declaration on this subject should not be received as settling the question wherever private rights are affected by it." 1

\section{From the Civil War to Vietnam}

Following the Reconstruction period, federal courts continued to accept war power issues and decide them in accordance with legal principles. That pattern persisted throughout the Spanish-American War, World War I, World War II, and the Korean War. Even in the middle of the Korean War, the Supreme Court was willing to tell President Harry Truman that he lacked authority to seize the steel mills he needed to prosecute the war. Only with the Vietnam War did judges begin to discover ways of not deciding these cases on their merits.

In 1889, the Supreme Court held that a statute excluding Chinese workers from the United States represented a constitutional exercise of legislative power. In so doing, the Court pointed to England's request that U.S. naval and political authorities act in concert with France against China. The request was denied, said the Court, because the administration understood that the authority to undertake offensive actions against another nation lies in Congress, not the executive branch. The secretary of state in his communication to the English government explained that the warmaking power of the United States "was not vested in the president but in Congress, and that he had no authority, therefore, to order aggressive hostilities to be undertaken." ${ }^{12}$

The Spanish-American War triggered some war power cases. The issue in a 1901 case was whether a U.S. military commander could impose duties on goods coming from the United States into Puerto Rico. The Court ruled that the duties imposed under presidential authority were valid prior to the ratification of the treaty of peace, but not after ratification. Although the president in legislating for a conquered country "may disregard the laws of that country, he is not wholly above the laws of his own." ${ }^{63}$ After rati-

60. United States $v$. Anderson, 76 U.S. (9 Wall.) 56, 70 (1870).

61. Ibid., 71. See also United States v. Russell, 13 Wall. 623 (1871) and The Protector, 12 Wall. 700 (1872).

62. The Chinese Exclusion Case, 130 U.S. 581,591 (1889).

63. Dooley v. United States, 182 U.S. 222, 234 (1901). 
fication of the peace treaty, Puerto Rico was entitled to free entry "until Congress otherwise constitutionally directed." 64

In another Spanish-American War case, the Court considered the seizure and detention by U.S. military and naval forces of a vessel owned by a Spanish corporation. To decide whether the vessel had been properly seized as enemy property and used for war purposes, the Court needed to decide when the war ended and determine the effects of the peace treaty. It ruled that the war did not cease until the exchange of ratifications of the Treaty of Paris in April 1899. The argument that the war had ended with the protocol and presidential proclamation of August 12, 1898, which suspended hostilities, was dismissed on the ground that "[a] truce or suspension of armies does not terminate the war, but ... suspends its operations." 65

In a case arising from the Boxer Rebellion, a circuit court had to decide whether the rebellion amounted to a war. President William McKinley sent 5,000 U.S. troops to China in 1900 to protect American citizens threatened by the rebellion. When Congress returned from recess, he declared that his initiative "involved no war against the Chinese nation" (Richardson 1897, 13: 6423). A U.S. serviceman, charged with murder and found guilty by a military court, was tried and convicted under the $58 \mathrm{th}$ article of war, which required that a general court martial be assembled in "time of war." The court first decided that a formal declaration by Congress was "unnecessary to constitute a condition of war." ${ }^{66}$ Because the United States occupied Chinese territory, there were conflicts between U.S. and Chinese troops, and Congress recognized "a condition of war" by making payments to the officers and troops engaged "on a war basis." At the time of the murder "there prevailed in China a condition of war, within the spirit and intent of the fifty-eighth article of war." ${ }^{67}$

In 1912, a district court decided whether military authorities had acted properly in making arrests without a warrant. Section 14 of the Penal Code empowered the president to employ the army to prevent the carrying on of any military expedition from the territory of the United States against the territory of any foreign state "with whom the United States are at peace" ( 35 Stat. 1090, $\$ 14$ ). However, the court held that the president did not have the authority, in time of peace, to use the military forces to arrest without a warrant and imprison without trial an alien merely suspected of violating the neutrality laws. His arrest contravened the Fourth Amendment and his continued detention was "repugnant not only to the fifth amendment, but also the sixth." 68

In a series of cases from 1919 to 1924, the Supreme Court refereed several war power disputes. The Court remarked that "[t]he war power of the United States, like its other powers and like the police power of the States, is subject to applicable constitutional limitations." ${ }^{69}$ Three cases involved the constitutionality of the War-Time Prohi-

64. Ibid., 235.

65. Hijo $v$ United States, 194 U.S. 315,323 (1904).

66. Hamilton v. MoClaughry, 136 Fed. 445, 449 (C.C. Kan. 1905).

67. Ibid., 451.

68. Ex parte Orozco, 201 F. 106, 112 (W.D. Tex. 1012), dismissed, 229 U.S. 633 (1913).

69. Hamilton v. Kentucky Distilleries Co., 251 U.S. at 146, 156 (1919). 
bition Act, which was attacked partly on the ground that Congress was continuing to prohibit the liquor traffic as a means of increasing war efficiency after the armistice with Germany had been signed on November 11, 1918. Congress subsequently passed legislation to prohibit the sale of liquor for the purpose of conserving manpower and increasing war efficiency ( 40 Stat. 1046). Private companies objected that between the date of enactment and the commencement of their lawsuit "it had become evident that hostilities would not be resumed; that demobilization had been effected; that thereby the war emergency was removed; and that when the emergency ceased the statute became void."70

The Court identified various actions by Congress and the president to show that demobilization was incomplete and that the president had refrained from issuing the proclamation declaring the termination of demobilization. ${ }^{71}$ The Court did not rule out the possibility that a case dealing with the cessation of war could be presented in which it would find that the political branches had transgressed their authority. Several other decisions explored the extent to which the political branches could continue emergency powers after the cessation of hostilities. ${ }^{72}$

Another World War I case dealt with governmental controls on pricing. The Lever Act of 1917, as amended in 1919, provided criminal penalties for companies that charged "unjust or unreasonable" rates or exacted "excessive prices." A company complained in court that the country was "virtually at peace" and Congress had no power to regulate the matter. Focusing on problems of vagueness with the statute, the Supreme Court held the Lever Act "void for repugnancy to the Constitution" and affirmed the district court's judgment quashing an indictment against the company. ${ }^{73}$.

In 1923, the Court decided several cases involving the seizure of enemy-held property, brought under the Trading with the Enemy Act. Companies objected that the emergency had ceased with the cessation of war but the Court deferred to congressional judgment. ${ }^{74}$ The following year, the Court seemed to signal that it might place limits on the exercise of the war power, in this case involving the regulation of rents in the District of Columbia. In returning the case to the Supreme Court of the District of Columbia, the Court cautioned that it "is not at liberty to shut its eyes to an obvious mistake, when the validity of the law depends upon the truth of what is declared. . . A law depending upon the existence of an emergency or other certain state of facts to uphold it may cease to operate if the emergency ceases or the facts change even though valid when passed." 75

In 1936, Justice George Sutherland in the Curtiss-Wright case expounded on the oft-quoted "very delicate, plenary and exclusive" nature of the president's powers in foreign affairs, with the president operating "as the sole organ of the federal government

70. Ibid., 159.

71. Ibid., 159-60.

72. Ruppert v. Caffey, 251 U.S. 264 (1920); United States v. Standard Brewery, 251 U.S. 210 (1920).

73. United States v. Cohen Grocery Co., 255 U.S. 81 (1921).

74. Commercial Trust Co. v. Miller, 262 U.S. 51 (1923); U.S. Trust Co. v. Miller, 262 U.S. 58 (1923); Abrenfeldt v. Miller, 262 U.S. 60 (1923).

75. Chastleton Corp. ข. Sinclair, 264 U.S. 543, 547-48 (1924). 
in the field of international relations." ${ }^{76}$ All Sutherland needed to do in this case was to announce that Congress could delegate more broadly to the president in external affairs than it could in domestic matters. But the expansive nature of his opinion provided fertile ground for a widely held belief that the field of foreign affairs is different, and that the likelihood of the courts applying the "political question" label to a given issue was much higher in cases falling under the "foreign relations" category (Post 1936, 119).

Sutherland cited John Marshall, when he was a member of the House of Representatives in 1800, for this remark: "The President is the sole organ of the nation in its external relations, and its sole representative with foreign relations."77 However, Marshall's speech in 1800 emphasized that the president was "sole organ" in implementing national policy after it had been decided jointly by Congress and the president, either by statute or by treacy (Fisher 2004, 20-21, 72). In his concurrence to the Steel Seizure Case of 1952, Justice Robert H. Jackson referred to much of Surherland's opinion in Curtiss-Wright as "dictum," ${ }^{18}$ but the decision continues to be widely cited to support "not only broad delegations of legislative power to the President but also the existence of independent, implied, and inherent powers for the President" (Fisher 2004, 73).

Federal courts during World War II handled a variety of war power issues. Not once did they rurn a case aside because it was inappropriate for judicial scrutiny. District and appellate courts at times challenged military and presidential authority, but the record of the Supreme Court was one of total deference to presidential judgment.

In 1942, the Supreme Court met in extraordinary summer session to decide the case of eight German saboteurs who were being tried by military tribunal. After nine hours of oral argument over a two-day period, the Court held in a brief per curiam that the tribunal was lawfully constituted, that the defendants were held in lawful custody, and had not shown cause for being discharged by writ of habeas corpus. ${ }^{79}$ Not until three months later did the Court release its full opinion in Ex parte Quirin to provide the legal reasons for the per curiam. ${ }^{80}$ The Court prided itself that the judiciary functioned, "in time of war as well as in time of peace, to preserve unimpaired the constitutional safeguards of civil liberty." ${ }^{81}$ Yet the history of this case shows no willingness of the Court to exercise judicial independence (Fisher 2003).

Also in 1942, the Court reviewed and upheld the government's power to mobilize the resources of the business community to support the war effort. ${ }^{82}$ Two years later, the Court upheld the price-fixing authority of the Office of Price Administration as a valid exercise of the war power. ${ }^{83}$ On the same day, the Court upheld a broad delegation of

76. United States v. Curtiss-Wright Export Corp., 299 U.S. 304, 320 (1936).

77. Ibid., 319.

78. Youngstown Sheet E Tube Co. v. Sauyer, 343 U.S. 579, 635-36 n. 2 (1952).

79. Ex parte Quirin, 63 S.Ct. 1-2 (1942). The per curiam is also reproduced in a footnote in Ex parte Quirin, 317 U.S. 1, 18-19 (1942).

80. Exparte Quirin, 317 U.S. 1 (1942).

81. Ibid., 19.

82. United States 2 Betblehem Steel Corp., 315 U.S. 289 (1942),

83. Yakus $v$. United States, 321 U.S. 414 (1944). 
rent control power to the administration. ${ }^{84}$ In sustaining this legislation, the Court was satisfied that Congress was dealing appropriately with conditions "created by activities resulting from a great war effort." 85 Even after the cessation of hostilities, the Court continued to uphold congressional statutes that attempted to deal with postwar conditions. ${ }^{86}$

In 1943 and 1944, the Supreme Court upheld first the curfew and later the internment of 120,000 Japanese Americans living on the West Coast, about two thirds of them natural-born U.S. citizens. ${ }^{87}$ In accepting and deciding these war power cases, the Court's deference to political and military authorities persuaded some scholars that the Court was effectively exercising a variant of the political question doctrine. While the Court in these cases "has, as a technical matter, affirmatively exercised its power of judicial review, as a practical matter [it] has effectively engaged in the prudential surrender of its review power to the political branches. ... [These cases were] exercises of the political question doctrine in everything but name" (Redish 1984-85, 1032-33, 1037, 1039).

Thus, although it decided these cases, the Court did not submit to its independent review the facts upon which the political branches based their conclusion of military necessity to order the exclusion and evacuation. In a dissent in the second case, Justice Jackson suggested that the Court might have been better off by not deciding the case, relying instead on the political question doctrine: "A judicial construction of the due process clause that will sustain this order is a far more subtle blow to liberty than the promulgation of the order itself. A military order, however unconstitutional, is not apt to last longer than the military emergency. Even during that period a succeeding commander may revoke it all. But once a judicial opinion rationalizes such an order to show that it conforms to the Constitution, or rather rationalizes the Constitution to show that the Constitution sanctions such an order, the Court for all time has validated the principle of racial discrimination in criminal procedure and of transplanting American citizens." 88

Also highly deferential to political and military authorities were the cases challenging martial law in Hawaii. Some district judges and circuit courts confronted military leaders, but not the Supreme Court (Fisher 2005b, 130-39). Only after the war did the Court place constraints on the operation of military law in Hawaii. ${ }^{89}$

In 1952, the Court decided that President Harry Truman had exceeded his constitutional authority when he directed the secretary of commerce to take possession of and operate most of the nation's steel mills. The government's legal strategy in litigating the case in district court - asserting that presidential power was inherent and plenary, and that Truman's action was not subject to judicial scrutiny-seriously backfired (Devins and Fisher 2002). District Judge David Pine concluded that a strike by steelworkers would "be less injurious to the public than the injury which would flow from

84. Bowles 1 Willingbam, 321 U.S. 505 (1944).

85. Ibid., 519.

86. Lichter v. United States, 334 U.S. 742 (1948); Woods v. Miller, 333 U.S. 138 (1948).

87. Hirabayasbi v. United States, 320 U.S. 81 (1943); Korematsu v. United States, 323 U.S. 214 (1944).

88. Korematsu v. United States, 323 U.S. at 246.

89. Duncan v. Kahanamoku, 327 U.S. 304 (1946). 
a timorous judicial recognition that there is some basis for this claim to unlimited and unrestrained Executive power, which would be implicit in a failure to grant the injunction." ${ }^{90}$ Divided 6 to 3 , the Supreme Court struck down Truman's action. ${ }^{91}$

Why did the Court challenge presidential authority at a time of active hostilities during the Korean War? Public opinion played an important role. Chief Justice William H. Rehnquist has remarked: "[A]nother, more deep-seated factor played a part in the tides of public opinion that were running at this time. There was a profound ambivalence on the part of much of the public about the Korean War, which was the principal basis upon which President Truman justified his seizure of the steel mills" (Rehnquist 1987, 96). The government's arguments in district court had damaged Truman: "The government's litigation strategy in the district court, reported blow by blow in the Washington newspapers, undoubtedly had an effect on how the case was finally decided by the Supreme Court" (ibid., 95-96).

Federal courts were presented with a number of cases in which they were asked to decide whether the hostilities in Korea amounted to a "war" in term of life insurance policies. Although the Truman administration persisted in calling the Korean War a "police action," one district judge remarked: "We doubt very much if there is any question in the minds of the majority of the people of this country that the conflict now raging in Korea can be anything but war." 92

\section{Vietnam: The Courts Step Aside}

The war in Vietnam and Southeast Asia sparked dozens of lawsuits challenging the president's authority to wage war without a formal declaration or explicit authorization ftom Congress. Initially, federal courts dismissed these cases on the grounds that they posed a political question, represented an unconsented suit against the United States, or that the plaintiffs lacked standing. The Supreme Court regularly denied petitions seeking its review of the questions involved. For the first time in the nation's history, federal courts were using the political question doctrine on a regular basis to avoid fundamental constitutional issues about the war power.

By the early 1970s, federal courts seemed ready to reach the merits of the constitutionality of America's involvement in Indochina. During this second phase, federal courts emphasized the "mutual cooperation" between the two political branches in the prosecution of the war and suggested that were it not for this joint support, the courts might decide against the president. By 1973, as U.S. participation drew to a close, some courts grew more bold, with one district judge stating that congressional actions did not constitute a valid expression of consent or provide evidence of sufficient cooperation. Another court issued an injunction to stop military involvement in Cambodia. Both

90. Youngstown Sheet E Tube Co. v. Sawyer, 103 F.Supp. 569.577 (D.D.C. 1952).

91. Youngstown Steel E Tube Co. v Sauyer, 343 U.S. 579 (1952).

92. Weissman v Metropolitan Life Ins. Co, 112 F.Supp. 420, 425 (D. Cal. 1953). For similar decisions, see Gagliormella v. Metropolitan Life Ins. Co., 122 F.Supp. 246, 250 (D. Mass. 1954); Carius v. New York Life Insurance Co., 124 F.Supp. 388, 390 (D. Ill. 1954). 
rulings were reversed on appeal, however, and the Supreme Court continued to deny certiorari. ${ }^{93}$

Language in a 1966 case, Luftig v. McNamara, illustrates the attitude of federal courts at the early stages of the war. An army private, to avoid being sent to Vietnam, argued that U.S. military action in that region was unconstitutional and the government had no authority to send him there. A district court dismissed the suit as "obviously a political question that is outside of the judicial function," and ruled further that the action was barred because the government "has not consented to be sued." On appeal, the D.C. Circuit agreed that the suit represented a political question and an unconsented suit. $^{94}$

Subsequent courts found it convenient to simply cite Luftig when dismissing challenges to the constitutionality of the Vietnam War. ${ }^{95}$ Courts consistently regarded these issues as a political question beyond judicial reach. ${ }^{96}$ In the law reviews during this period, scholars were generally critical of the failure of courts to decide the merits of these cases (Schwartz and McCormack 1968; Velvel 1968; Loeb 1969). Articles cautioned that the Supreme Court's record of avoidance might encourage widespread civil disobedience from citizens who concluded that constitutional questions can no longer be resolved in the courts (Hughes 1968; Moore 1969). Judicial abdication, they argued, contributed to the erosion of formal structural guarantees placed in the Constitution (Tigar 1970). Still, federal judges refused to analyze the competing constitutional arguments. ${ }^{97}$

After this period of judicial passivity, courts began to invoke the political question doctrine more carefully and on much narrower grounds. Judges now showed an increasing willingness to weigh the competing constitutional positions. The turning point came in two cases decided in 1970 and relied upon in subsequent litigations. In the first case, an enlisted army private challenged the legality of an order requiring him to report for duty to South Vietnam, claiming that the war had not been properly authorized by Congress. After a district court denied his motion for a preliminary injunction, ${ }^{98}$ the Second Circuit gave thoughtful consideration to the circumstances that would surmount the political question doctrine. It pointed out that if the president had engaged in prolonged

93. Atlee v. Laird is the only case involving the Southeast Asian conflict in which the Supreme Court issued a summary affirmance. Atlee v. Laird, 347 F.Supp. 689 (E.D. Pa. 1972), aff'd without opinion, 411 U.S. 911 (1973).

94. Luftig v. McNamara, 252 F.Supp. 819, 821 (D.D.C. 1966), aff'd, 373 F.2d 664 (D.C. Cir. 1967), cert. denied, 387 U.S. 945 (1967).

95. For example, Mora 1. MrNamara, 387 F.2d 862 (D.C. Cir. 1967), cert. denied, 389 U.S. 934 (1967). See also Velvel v. Johnson, 287 F.Supp. 846 (D.D.C. 1968), aff'd, 415 F.2d 236 (10th Cir. 1969), cert. denied, 396 U.S. 1042 (1970), and McArtbur v Clifford, 402 F.2d 58 (4th Cir. 1968), cert. denied, 393 U.S. 1002 (1968).

96. United States v. Sisson, 294 F.Supp. $511,515,520$ (D. Mass. 1968). See also United States $v$ Mitchell, 354 F.2d 767 (2d Cir. 1966), aff'd, 369 F.2d 323 (2d Cir. 1966), cert. denied, 386 U.S. 972 (1967); United States v. Hart, 382 F.2d 1020 (3d Cir. 1967), cert. denied, 391 U.S. 956 (1968); United States v. Holmes, 387 F.2d 781 (7th Cir. 1967), cert. denied, 391 U.S. 936 (1968); and Morse v. Boswell, 289 F.Supp. 812 (D. Md 1968), aff'd, 401 F.2d 544 (4th Cir. 1968), cert. denied, 393 U.S. 1052 (1969).

97. Pietsch v. President of the United States, 434 F.2d 861, 863 (2d Cir. 1970); Davi v. Laird, 318 E.Supp. 478, 482 (W.D. Va 1970); Massachusetts v. Laird, 400 U.S. 886 (1970).

98. Berk v Laird, 317 F.Supp. 715 (E.D. N.Y. 1970). 
military activities without any significant authorization from Congress, "a court might be able to determine that this extreme step violated a discoverable standard for some mutual participation by Congress in accordance with Article I, section 8." However, because Congress had passed the Gulf of Tonkin Resolution in August 1964 and had enacted appropriations and other statutes that supported the war, the constitutional requirement of legislative consent (or "mutual participation") appeared to be satisfied. ${ }^{100}$

When the case went back to the district court, it did not rely on the political question doctrine. It listened to the merits from both sides, reviewed the early distinction between total war and partial war, and decided that Congress-through the Gulf of Tonkin Resolution, appropriations bills, and authorization bills-had authorized hostilities in Vietnam. ${ }^{101}$ The court remarked that "[ $\left.\mathrm{t}\right] \mathrm{his}$ is not a case where the President relied on his own power without any supporting action from Congress, as in the steel seizure." 102

A similar decision was reached by another district court in 1970. In analyzing the constitutional provisions relating to war and asking whether the dispute could be decided by standards that judges find manageable, the court found no bar by the political question doctrine. "No unusual subject matter is presented. Decisions in the entire area of the taking and arresting of combat action are exclusively political in kind, but determining whether or not a political decision has been taken by the appropriate set of governmental acts inescapably presents a purely judicial question when the existence or non-existence of a valid political authorization as the source of a particular command is drawn in question by one directly affected by it in his individual liberty as a citizen." 103

The court decided other matters about the allocation of the war power, stating that neither the language of the Constitution nor the debates at the time "leave any doubt that the power to declare war and wage war was pointedly denied to the presidency. ... The debates . . . are clear that . . the power to make war and peace are legislative." 04 Again: "The language of the Constitution makes the war power a legislative power rather than an executive power." 105 Having defined the constitutional boundaries, the court decided that military activities in Vietnam had been authorized by Congress in various authorization and appropriations statutes, and that the record demonstrated "collaborative action" between the two branches. ${ }^{106}$

The Second Circuit, in affirming this decision, agreed that judicial scrutiny of Congress's duty to participate in warmaking was not foreclosed by the political question doctrine. ${ }^{107}$ It also ruled that the president had no constitutional authority to unilaterally initiate offensive military action, and that Congress had to share in the decision to wage

99. Berk v. Laird, 429 F.2d 302, 305 (2d Cir. 1970) (emphasis in original).

100. Ibid.

101. Berk v. Laird, 317 F.Supp. 715, $721-27$ (E.D. N.Y. 1970).

102. Ibid., 729.

103. Orlando v. Laird, 317 F.Supp. 1013, 1016 (E.D. N.Y. 1970).

104. Ibid.

105. Ibid., 1017.

106. Ibid.

107. Orlando v. Laird, 443 F.2d 1039, 1042 (2d Cir. 1970), cert. denied, 404 U.S. 869 (1971). 
war. The task of the judiciary was therefore to determine whether there was sufficient legislative action to authorize or ratify military activity in Vietnam, and on that issue the Second Circuit was satisfied that Congress and the president had acted jointly in supporting military operations in Southeast Asia. ${ }^{108}$

A Second Circuit decision in 1971 followed the same pattern. The court held that the legislative action in extending the Selective Service Act and in appropriating billions of dollars to carry on military operations in Vietnam was sufficient to ratify and approve measures taken by the president, even in the absence of the Gulf of Tonkin Resolution. ${ }^{109}$ At the time of the court's decision, the Tonkin Gulf Resolution had been repealed (84 Stat. 2055, $\S 12$ ). At a minimum, the court said that the Constitution required some evidence of mutual cooperation between the political branches in the prosecution of military activities in Vietnam. It then issued these words of caution: "If the Executive were now escalating the prolonged struggle instead of decreasing it, additional supporting attion by the Legislative Branch over what is presently afforded, might well be required."110

The issue of escalation returned to the Second Circuit in 1973. A plaintiff sought a declaratory judgment that an order to mine the ports and harbors of North Vietnam and continue air and naval strikes was unlawful without explicit congressional authorization. The court dismissed the case on the ground that the issue was political in nature and beyond the scope of the court's jurisdiction. ${ }^{111}$ Although the district court had considered judicial review appropriate if the president escalated the war without additional legislative support, the Second Circuit considered that even the district court's limited inquiry was improper because the courts lacked competence to make such judgments. ${ }^{112}$ Yet the Second Circuit acknowledged that some war power issues might be appropriately adjudicated, such as a "radical change in the character of war operations-as by an intentional policy of indiscriminate bombing of civilians without any military objective." 113 It also suggested that judicial review might be appropriate if Congress withdrew funding.

Following these decisions, all of which expressed a competence on the part of the judiciary to decide some war power issues, some courts began to retreat by relying on standing and the political question doctrine to avoid discussion of the merits. ${ }^{114}$ The claim of mutual cooperation between the executive and legislative branches in the war effort reappeared in other cases. The implication was that absent such assent or support

108. Also on the political question doctrine, see Mottola v. Nixon, 318 F.Supp. 538 (N.D. Cal. 1970), rev'd, 464 F.2d 178 (9th Cir. 1972).

109. DaCosta v. Laird, 448 F.2d 1368, 1369 (2d Cir. 1971), cert. denied, 405 U.S. 979 (1972).

110. Ibid. (emphasis added).

111. DaCosta v. Laird, 471 F.2d 1146, 1147 (2d Cir. 1973).

112. Ibid., 1155.

113. Ibid., 1156.

114. Campen v. Nixon, 56 F.R.D. 404 (N.D. Cal. 1972); Atlee v. Laird, 347 F.Supp. 689 (E.D. Pa 1972) (three-judge court), aff'd, 411 U.S. 911 (1973); Gravel v. Laird, 347 F.Supp. 7 (D.D.C. 1972); Samoff v. Connally, 457 F.2d 809 (9h Cir. 1972); Head v. Nixon, 342 F.Supp. 521 (E.D. La. 1972), aff d, 468 F.2d 951 (5th Cir. 1972). 
from the legislative branch, presidential military initiatives might be invalidated by the courts. ${ }^{115}$

Several lawsuits in 1973 marked a decisive step by courts in dismissing the political question doctrine. In 1973, thirteen members of Congress sought an injunction against the war in Indochina unless Congress explicitly authorized it. Although the D.C. Circuit held that the plaintiffs had standing to sue-because the House of Representatives had the duty to consider whether to impeach the president-the court declined to adjudicate the question of whether the president had exceeded his constitutional authority. The court ruled that the ingredients needed for adjudication in this particular case were not available and the question was, therefore, "political." 116 Yet it added: "We are now persuaded that there may be, in some cases, such [judicial] competence."

In another 1973 case - one of the first brought after the withdrawal of American troops from Vietnam and the release of American prisoners of war-a district court went so far as to hold that the president would be enjoined from engaging in combat operations in Cambodia. ${ }^{118}$ The court granted a member of Congress standing and held that the political question doctrine did not warrant dismissal of the case. ${ }^{119} \mathrm{~A}$ month later, the court noted that Congress had taken steps to prohibit the use of funds for the bombing of Cambodia, President Nixon had vetoed the bill, and Congress was unable to override the veto. The political branches then agreed on language that allowed the bombing to continue until August 15, 1973, after which the use of funds for military activities in Southeast Asia would be prohibited. ${ }^{120}$ The compromise amendment that Congress had adopted after failing to override the veto could not, said the courr, amount to a ratification by the legislative branch of the intended bombing. It "cannot be the rule," said the court, "that the President needs a vote of only one-third plus one of either House in order to conduct a war, but this would be the consequence of holding that Congress must override a Presidential veto in order to terminate hostilities which it has not authorized." 221 That decision was reversed by the Second Circuit, which held that the challenge presented a nonjusticiable question beyond the scope of its cognizance. ${ }^{122}$ Yet the court also accepted the "August 15 Compromise" as evidence that Congress consented to the Cambodian bombing. ${ }^{123}$

115. Commonwealth of Massachusetts v. Laird, 327 F.Supp. 378, 381 (D. Mass. 1971); Commonwealth of Massarhusetts v. Laird, 451 F.2d 26, 34 (1st Cir. 1971); Atlee v. Laird, 347 F.Supp. 689, 694 (E.D. Pa.1972), aff d summarily, 411 U.S. 911 (1973); Drinan v. Nixon, 364 F.Supp. 854, 856 (D. Mass. 1973).

116. Mitchell $v$ Laird, 488 F.2d 611 (D.C. Cir. 1973).

117. Ibid., 614

118. The effect date of the injunction would be postponed, however, in order to allow the administration to apply for a stay from the appellate court. Holtzman $v$ Schlesinger, 361 F.Supp. 553 (E.D. N.Y. 1973).

119. Holtzman v. Richardson, 361 F.Supp. 544 (E.D. N.Y. 1973).

120. Holtzman v. Schlesinger, 361 F.Supp. 553, 559-60 (E.D. N.Y. 1973).

121. Ibid., 565.

122. Holtzman v. Schlesinger, 484 F.2d 1307 (2d Cir. 1973).

123. Ibid., 1313. The Second Circuit's decision was sustained by the Supreme Court; 414 U.S. 1304 , 1316, 1321 (1973). See also Harrington v. Scblesinger, 373 F.Supp. 1138 (E.D. N.C. 1974), aff'd, 528 F.2d 455 (4th Cit. 1975). 


\section{From Ford to Bush II}

Lawsuits continued to challenge presidential authority to conduct military operations without authorization from Congress. These challenges were regularly dismissed on a variety of grounds, including the doctrines of ripeness, mootness, political questions, equitable discretion, and standing. These cases, however, did not entirely close the door to judicial involvement. They underscored that Congress must assert its institutional remedies before resorting to litigation. Unless lawmakers demonstrated their willingness to act, the courts would not intervene. They would enter the fray once a war power dispute became "ripe" for adjudication, but the clash had to be clear and resolute, the branches must have reached a constitutional impasse or deadlock, and a majorityas opposed to a small percentage — - of the legislative body needed to make clear its opposition to the particular action challenged in the courts.

In 1980, former crewmen of a privately owned cargo vessel, the Mayaguez, brought a suit against the United States to seek damages for personal injuries allegedly suffered during U.S. military operations in response to the seizure of the vessel by Cambodian gunboats. The crewmen claimed negligence on the part of the United States in undertaking and executing the military operation and a breach of duty to warn the Mayaguez of the danger of such capture. A district court held that the government's decision to undertake the rescue operation involved a basic policy judgment as to national interest and, therefore, its execution fell within the exception for discretionary functions under the Suits in Admiralty Act. ${ }^{124}$ The claim of negligence by the government in connection with the military operation presented a nonjusticiable political question.

The next set of cases involved military operations by the Reagan administration in El Salvador and Nicaragua. The courts disposed of these cases largely on the ground that the plaintiffs were members of Congress who had adequate institutional tools at their disposal for challenging the president. Also, the fact finding needed to determine whether U.S. forces had been introduced into hostilities or imminent hostilities made the case nonjusticiable. The job of determining such facts was for Congress, not the courts. ${ }^{125}$ At the same time, the judiciary rejected the administration's claim that the case barred the courts from interfering with executive discretion in the foreign affairs field, or that the issue was political because it involved the allocation of power between the executive and legislative branches. Such questions had been decided in the past by federal courts. Moreover, if Congress passed legislation to withdraw armed forces and the president disregarded it, "a constitutional impasse appropriate for judicial resolution would be presented." 126

In a suit arising out of U.S. involvement in Nicaragua, a district court held that the case presented nonjusticiable political questions inappropriate for the courts. ${ }^{127}$ When the decision was affirmed by the D.C. Circuit, a concurring opinion by Judge

124. Rappenecker v. United States, 509 F.Supp. 1024, 1028-29 (N.D. Cal. 1980).

125. Crackett v. Reagan, 558 F.Supp. 893,898 (D.D.C. 1982), aff'd, 720 F.2d 1355 (D.C. Cir. 1983), cert. denied. 467 U.S. 1251 (1984).

126. 558 F.Supp. at $898-99$.

127. Sanchez-Espinoza v. Reagan, 568 F.Supp. 596, 597-98 (D.D.C. 1983). 
Ruth Bader Ginsburg cited language from Goldwater v. Carter that "[i]f the Congress chooses not to confront the President, it is not our task to do so." 128 The case was not ripe for judicial review because a majority of Congress had yet to throw down a gauntlet, and in fact Congress had expressly provided funds that supported paramilitary operations in Nicaragua.

Two other cases during the Reagan years were handled in a similar manner. A district court dismissed a lawsuit by Congressman John Conyers and ten other members of Congress, who challenged the constitutionality of the invasion of Grenada. The court pointed out that the lawmakers had plenty of "in-house remedies available to them." ${ }^{29}$ On appeal, the case was dismissed on the ground of mootness, the invasion having terminated at the time the case reached the court. ${ }^{130}$ Military operations ordered by President Reagan in the Persian Gulf region triggered several cases, but these were dismissed because the plaintiffs were members of Congress who failed to attract a majority of colleagues to confront the president. The political question doctrine blocked the exercise of jurisdiction. ${ }^{131}$ Yet the court acknowledged that judicial review might be appropriate under certain conditions: "A true confrontation between the Executive and a unified Congress, as evidenced by its passage of legislation to enforce the Resolution, would pose a question ripe for judicial review." 132

In December 1990, a district court decided a case brought by fifty-three members of the House of Representatives and one senator, who requested an injunction to prevent President George H. W. Bush from initiating war against Iraq without first securing a declaration of war or other congressional authorization. District Judge Harold Greene held that the controversy was not ripe for judicial determination because the use of military force was neither certain nor inevitable. At the same time, he dismissed the Justice Department's claim that only the political branches are able to determine whether the country is at war. He found the argument "far too sweeping to be accepted by the courts. If the Executive had the sole power to determine that any particular offensive military operation, no matter how vast, does not constitute war-making but only an offensive military attack, the congressional power to declare war will be at the mercy of a semantic decision by the Executive. Such an 'interpretation' would evade the plain language of the Constitution, and it cannot stand." ${ }^{133}$ He specifically held that the political question doctrine did not bar adjudication of the issue ${ }^{134}$ and that plaintiffs had "adequately alleged a threat of injury in fact necessary to support standing." 135

128. Sanchez-Espinoza v. Reagan, 770 F.2d 202, 211 (D.C. Cir. 1985)

129. Conyers v. Reagan, 578 F.Supp. 324, 326 (D.D.C. 1984)

130. Conyers $v$. Reagan, 765 F.2d 1124 (D.C. Cir. 1985).

131. Lowry \% Reagan, 676 F.Supp. 333 (D.D.C. 1987), aff'd, No. $87-5426$ (D.C. Cir. 1988).

132. Ibid., 339.

133. Dellums v. Bush, 752 F.Supp.1141, 1145 (D.D.C. 1990).

134. Judge Greene pointed out that "if the War Clause is to have its normal meaning, it excludes from the power to declare war all branches other than the Congress. It also follows that if the Congress decides that United States forces should not be employed in foreign hostilities, and if the Executive does not of its own volition abandon participation in such hostilities, action by the courts would appear to be the only available means to break the deadlock in favor of the constitutional provision." 1 bid., $1144 \mathrm{n} .5$.

135. Ibid., 1148 . 
As with other courts, Judge Greene looked to an open confrontation between the two branches to justify resolution by the judiciary. Emphasizing that the legislative branch- "as distinguished from a fraction thereof"-must express itself on the necessary military moves in the Arabian desert, he ruled: "In short, unless the Congress as a whole, or by a majority, is heard from, the controversy here cannot be deemed ripe; it is only if the majority of the Congress seeks relief from an infringement on its constitutional wardeclaration power that it may be entitled to receive it." 136

Two other cases challenging Bush's actions in Iraq were brought by a sergeant of the National Guard and a private citizen. The first case was dismissed on the ground that the deployment orders and activities in the Persian Gulf were not subject to judicial review, ${ }^{137}$ and the second because the citizen did not establish a "case or controversy" necessary for federal jurisdiction. ${ }^{138}$

The next judicial test involved President Bill Clinton's decision in 1999 to order the bombing of Yugoslavia without congressional authorization. A district court held that the plaintiffs lacked standing because their complaint-the alleged "nullification" of congressional votes-was not sufficiently concrete. To gain standing, legislative plaintiffs had to allege that their votes had been "completely nullified" or "virtually held for naught." 139 They needed to show a "constitutional impasse" or "actual confrontation" between the elected branches. Otherwise, small groups of legislators or even individual members could seek a judicial remedy instead of using the available political process. The court found no such constitutional impasse. The case would have been ripe for judicial determination had Congress directed Clinton to remove U.S. forces and he refused, or if Congress had withheld funds for the air strikes in Yugoslavia and he decided "to spend that money (or money earmarked for other purposes) anyway." 140 To the extent that Clinton argued that "every case brought by a legislator alleging a violation of the War Powers Clause raises a non-justiciable political question, he is wrong." ${ }^{41}$

The D.C. Circuit affirmed on the same grounds of lack of standing. It concluded that the plaintiffs lacked standing because they possessed legislative power to force the president to withdraw U.S. troops, to cut off funds, or to impeach the president if he disregarded congressional authority. ${ }^{142}$ What makes this appellate decision interesting is that each of the three judges on the panel wrote separate opinions. To Judge Laurence Silberman, no one had a legal right to challenge the president's use of military force. Such claims were nonjusticiable because courts lacked discoverable and manageable standards to decide questions related to the War Powers Clause. Judge David Tatel rejected the view that the case posed a nonjusticiable political question or that there was a lack of manageable standards. He believed that the case presented purely legal issues, calling

136. Ibid., 1151. No appeal was taken from the district court decision.

137. Ange v. Bush, 752 F.Supp. 509 (D.D.C. 1990).

138. Pietsch v. Bush, 755 F.Supp. 62 (E.D. N.Y. 1991).

139. Campbell v. Clinton, 52 F.Supp.2d 34, 43 (D.D.C. 1999).

140. Ibid.

141. Ibid., n. 5 (emphasis in original).

142. Campbell v. Clinton, 203 F.3d 19, 23 (D.C. Cir. 2000). 
on the courts to determine the proper constitutional allocation of power between Congress and the president.

\section{Litigation after $9 / 11$}

The first Iraq case and the war in Yugoslavia posed difficult issues for the courts. Congress had not yet authorized military action when Judge Greene decided the case in December 1990, and at no time did Congress ever specifically authorize the war against Yugoslavia. After the terrorist attacks of $9 / 11$, Congress unambiguously authorized military operations against the Taliban and al Qaeda in Afghanistan. Then, in October 2002, Congress authorized the second war against Iraq. Six members of Congress, along with soldiers and parents, filed a lawsuit challenging the authority of President George W. Bush to conduct the war. A district court held that the dispute involved political questions beyond the authority of the judiciary to resolve. Only if the political branches were clearly and resolutely in opposition could the courts take and decide the case. ${ }^{143}$ The First Circuit affirmed the district court ruling, but not on the political question doctrine, which it found "famously murky." 144 Instead, it based its decision on ripeness. Although Congress had authorized military operations, diplomatic negotiations were still underway when the appellate court issued its ruling.

The shock of $9 / 11$ initially produced a compliant judiciary, willing to defer to executive initiatives and judgments. The executive branch continued to flex its muscles, insisting that it had the constitutional authority to detain hundreds of individuals in Guantánamo Bay and hold them indefinitely until the government decided it was time for their release. President Bush, on November 13, 2001, issued a military order authorizing the creation of military tribunals to try noncitizens who had given assistance to al Qaeda. He claimed that he had authority to designate U.S. citizens "enemy combatants" and hold them for years without giving them access to an attorney, charging them with a crime, or bringing them before a court for trial.

These sweeping assertions of presidential power finally led to the Supreme Court's decisions on June 28, 2004. Writing for the plurality in Hamdiv. Rumsfeld, Justice Sandra Day O'Connor rejected the government's position that separation of powers principles "mandare a heavily circumscribed role for the courts." A state of war, she said, "is not a blank check for the President when it comes to the rights of the Nation's citizens."145 This judicial rhetoric was not matched by the issuance of clear standards from the Court, either in this case or Rasul v. Bush (Fisher 2005b, 210-49).

Lower courts were therefore latgely on their own in scrutinizing the administration's claims for presidential power. On January 19, 2005, District Judge Richard J. Leon ruled that the foreigners imprisoned at Guantánamo had no legal way of chal-

143. Doe v. Bush, 240 F.Supp.2d 95 (D. Mass. 2002).

144. Doe v. Bush, 323 F.3d 133, 140 (1st Cir. 2003).

145. Hamdi $v$. Rumsfeld, 124 S.Cr. 2633, 2650 (2004). 
lenging their detentions in federal court. ${ }^{146}$ Other district judges, however, sharply rejected the legal arguments put forth by the Justice Department. On January 31, District Judge Joyce Hens Green ruled that the special tribunals created in Guantánamo to satisfy the Supreme Court's decision were unconstitutional by denying due process to the detainees who sought to challenge their classification. ${ }^{147}$ In another setback for the administration, on February 28 a district judge in South Carolina held that the government must release Jose Padilla, a U.S. citizen who President Bush had designated as an enemy combatant, within forty-five days unless the government charged him with a crime. ${ }^{148}$ Padilla had been held incommunicado for almost three years.

The sharp disagreements between Judges Silberman and Tatel in the D.C. Circuit underscore the rift that still exists among federal judges on war power issues and the political question doctrine. Contrary to the general impression that war power disputes present delicate political issues beyond the scope of judicial scrutiny, courts have generally regarded the exercise of war powers by the political departments as subject to independent judicial scrutiny. Throughout the past two centuries, federal courts accepted and decided a broad range of issues involving military operations. Most of those lawsuits were brought by private individuals who expected their legal claims to be settled on the legal and constitutional merits.

While courts often acknowledge the president's broad discretionary powers in foreign policy and military actions, they usually do so after interpreting what Congress has authorized by statute. Even at the height of judicial unwillingness to reach the constitutional merits of the Vietnam War, the courts looked for some form of congressional approval or at least ratification of presidential war initiatives. They also intimated, repeatedly, that absent such a support (express or implicit) the decisions they reached might have turned against the president.

Public pressure has affected judicial rulings on the war power. As the Korean and Vietnam Wars continued and popular support diminished, the courts appeared to be responsive to public opinion. District Judge Pine and the Supreme Court were aware of the sharp public disapproval of President Truman's broad claims of executive power. Sentencing of Vietnam War resisters seemed to decline in severity as public opinion turned against the war (Kritzer 1977, 1979; Graebner 1973-74).

Although courts often decide war power disputes involving private citizens and private corporations, they are much more reluctant to decide cases brought by members of Congress. It is not enough for a dozen or so lawmakers to initiate a lawsuit. Unless there is evidence of a clear and resolute conflict between the political branches, and unless Congress as an institution is prepared to confront the president, the judiciary is likely to dismiss the case on various grounds. Lawsuits involving war power boundary disputes between the political branches will be addressed only if perfectly "ripe" for judicial

146. Khalid v. Bush, Civil Case No. 1:04-1142 (RJL); Boudediene v. Bush, Civil Case No. 1:04-1 166 (RJL) (D.D.C. 2005).

147. In re Guantanamo Detainee Cases, Civil Action Nos. 02-CV-0299 (CKK), et al. (D.D.C. 2005 ).

148. Padilla v. Hanft, Civil Action No. 2:04-2221-26AJ (D.S.C. 2005) 
resolution. When Congress decides to press a war power issue in the courts, it must do so as a body and after taking votes in opposition to presidential actions.

The protection of individual rights and liberties depends now, as it did two centuries ago, on a vigorous system of checks and balances. In no area of federal power is that constraint more crucial than the decision to go to war. Without judicial and legislative controls, this part of presidential power shades into the monarchy that the Framers thought they had put behind them. A restoration of judicial and legislative checks depends on an understanding that the concentration of war power in the presidency is unhealthy for constitutional liberty, the country, and the world.

\section{References}

Champlin, Linda, and Alan Schwarz. 1985. Political question doctrine and the allocation of the foreign affairs power. Hofstra Law Review 13: 215-56.

Corn, Geoffrey S. 1998. Presidential war power: Do the courts offer any answers? Military Law Review 157: 180-255.

Corwin, Edward A. 1957. The president: Office and powers. New York: New York University Press.

Devins, Neal, and Louis Fisher. 2002. The Steel Seizure Case: One of a kind? Constitutional Commentary 19: 63-86.

Finkelstein, Maurice. 1924. Judicial self-limitation. Harvard Law Review 37: 338-64.

Firmage, Edwin B. 1977. The war powers and the political question doctrine. University of Colorado Law Review 49: 65-101.

Fisher, Louis. 2003. Nazi saboteurs on trial: A military tribunal and presidential power. Lawrence: University Press of Kansas.

- 2004. Presidential war power. Lawrence: University Press of Kansas.

2005a. Scholarly support for presidential wars. Presidential Studies Quarterly 35: 590-607.

2005b. Military tribunals and presidential power: American Revolution to the war on terrorism. Lawrence: University Press of Kansas.

Franck, Thomas M. 1992. Political questions/judicial answers: Does the rule of law apply to foreign affairs? Princeton, NJ: Princeton University Press.

Glennon, Michael J. 1990. Constitutional diplomacy. Princeton, NJ: Princeton University Press.

Gold, A. E. 1923. Jurisdiction of the Supreme Court over political questions: What is a political question? Cornell Law Quarterly 9: 50-54.

Graebner, Dianne Bennett. 1973-74. Judicial activity and public attitude: A quantitative study of Selective Service sentencing in the Vietnam War period. Buffalo Law Review 23: 465-98.

Henkin, Louis. 1996. Foreign affairs and the United States Constitution. Oxford, UK: Clarendon Press.

Hughes, Graham. 1968. Civil disobedience and the political question doctrine. New York University Law Review 43: 1-19.

Kritzer, Herbert M. 1977. Political correlates of the behavior of federal district judges: A "best case" analysis. Journal of Politics 40: 25-58.

1979. Federal judges and their political environment. American Journal of Political Science 12: 194-207.

Loeb, Louis. 1969. The courts and Vietnam. American University Law Review 18: 376-97.

May, Christopher N. 1989. In the name of war: Judicial review and the war powers since 1918. Cambridge, MA: Harvard University Press.

Moore, John Norton. 1969. The justiciability of challenges to the use of military forces abroad. Virginia Journal of International Law 10: 85-107.

Neustadt, Richard E. 1964. Presidential power. New York: Signet Books.

Post, Charles Gordon, Jr. 1936. The Supreme Court and political questions. Baltimore: Johns Hopkins University Press. 
Redish, Martin. 1984-85. Judicial review and the "political question." Nortbwestern University Law Review 79: 1031-61.

Rehnquist, William H. 1987. The Supreme Court: How it was, how it is. New York: Morrow.

Richardson, James P., ed. 1897. A compilation of the messages and papers of the presidents. Washington, DC: Bureau of National Literature.

Schwartz, Warren F, and Wayne McCormack. 1968. The justiciability of legal objections to the American military effort in Vietnam. Texas Law Review 46: 1033-53.

Sheffer, Martin S. 1999. The judicial development of presidential war powers. Westport, CT: Praeger.

Tigar, Michael E. 1970. Judicial power, the "political question doctrine," and foreign relations. UCL.A Review 17: 1135-79.

Velvel, Lawrence. 1968. The war in Viet Nam: Unconstitutional, justiciable, and jurisdictionally attackable. Kansas Law Review 16: 449-503(e).

Weston, Melville Fuller. 1925. Political questions. Harvard Law Review 38: 296-333.

Wormuth, Francis D., and Edwin B. Firmage. 1986. To chain the dog of war: The war power of Congress in bistory and law. Urbana: University of Illinois Press. 